\title{
As reservas legais e as áreas de preservação permanente como limitadoras do direito de propriedade e sua destinação econômica
}

\author{
Reservations and legal areas of permanent \\ preservation as limiting the law of ownership \\ and its economic destination
}

\begin{abstract}
Felipe André Dani ${ }^{[a]}$, Álvaro Borges de Oliveira ${ }^{[b]}$, Débora Sabetzki Barros ${ }^{[c]}$
[a] Mestre em Ciências Jurídicas pela Universidade do Vale do Itajaí/UNIVALI, Área de Concentração: Direito e Atividade Portuária - TRANSNACIONALIZAÇÃO, Bacharel em Direito pela Universidade de Passo Fundo, Passo Fundo, RS - Brasil, e-mail: felipeandre2000@hotmail.com

[b] Doutor em Engenharia de Produção pela Universidade Federal de Santa Catarina (UFSC), professor titular dos cursos de Doutorado, Mestrado e Graduação em Ciência Jurídica na Universidade do Vale do Itajaí (Univali), Florianópolis, SC - Brasil, e-mail: alvaro@univali.br

[c] Graduanda do curso de Direito pela Universidade do Vale do Itajaí/UNIVALI - Campus Balneário Camboriú, Camboriú, SC - Brasil, e-mail: deborasabetzki@gmail.com
\end{abstract}

\section{Resumo}

Inicia-se o presente artigo abordando-se o princípio da propriedade e suas transformações diante da mutabilidade e anseios sociais. Parte-se de um conceito clássico de propriedade, adotado pelo Código Civil Brasileiro, para uma definição que dá ênfase a propriedade 
dinâmica, bem como, sua função social, com apego à função social ambiental da propriedade, sob o prisma de limitador do absolutismo do proprietário. Explana-se sobre as reservas legais e as áreas de preservação permanente, como institutos do Direito Ambiental restritivos à propriedade, porém, através de um viés econômico, buscando uma destinação a estas áreas. Ao final do presente artigo, busca-se um equilíbrio entre o Direito Ambiental e o Direito Econômico, aparentemente conflitantes, decorrente da limitação econômica sofrida pela propriedade privada, vista como direito individual e absoluto, e a função social, com caráter ambiental, diante da obrigação ao particular de preservar e manter o meio ambiente para atingir a função social da propriedade, de acordo com corolários constitucionais.

Palavras-chave: Princípio da propriedade. Propriedade dinâmica. Função social ambiental. Reservas legais. Áreas de preservação permanente.

\section{Abstract}

It begins this article which looks at the principle of ownership and its changes on the mutability and social concerns. It starts with a classical concept of property, adopted by the Brazilian Civil Code, a definition that emphasizes the dynamic property, as well as its social function, social function with attachment to the property's environmental, through the prism of the absolutism of the limiter owner. Explains up on the legal reserve and permanent preservation areas, such as the Environmental Law institute restrictive property, however, through an economic bias, seeking an allocation to these areas. At the end of this article, we seek to balance the Environmental Law and Economic Law, apparently conflicting, due to the economic limitation suffered by private property, individual right and seen as absolute, and social function, with an environmental nature, faced with the obligation to particular to preserve and maintain the environment to achieve the social function of property, according to constitutional corollaries.

Keywords: Principle of the property. Dynamic property. Ambient social function. Legal reserves. Areas of permanent preservation.

\section{Introdução}

O presente artigo aborda o princípio da propriedade e suas transformações diante da mutabilidade e anseios sociais; aborda a função social, com apego à função social ambiental da propriedade sob o prisma 
de limitador do absolutismo do proprietário. Explana-se sobre as reservas legais e as áreas de preservação permanente, como institutos do Direito Ambiental restritivos à propriedade, porém, através de um viés econômico, buscando uma destinação a estas áreas.

\section{Princípio da propriedade}

A propriedade é conceituada como direito real subjetivo de usar, gozar, dispor e reivindicar o bem de quem o possua ou detenha injustamente, com o dever correlato de fazê-lo, levando em conta o bem-estar social, conceito este, disposto pela função social da propriedade.

Aristóteles (1988, p. 13), no livro A Política, traz algumas idéias de supremacia do interesse público sobre o privado: "na ordem da natureza, o Estado se coloca antes da família e antes de cada indivíduo, pois que o todo deve forçosamente ser colocado antes da parte".

Ainda segundo Aristóteles (1988, p. 29), quando faz referência à propriedade individual, que despertaria maior interesse e cuidado do que a propriedade comum:

esta proposição tudo é meu, apresenta ainda um outro inconveniente: é que nada inspira menos interesse que uma coisa cuja posse é comum a um grande número de pessoas. Damos uma importância muito grande ao que propriamente nos pertence, enquanto que só ligamos às propriedades comuns na proporção do nosso interesse pessoal. Entre outras razões, elas são mais desprezadas porque são entregues aos cuidados de outrem.

Segundo Fernanda de Salles Cavedon (2003, p. 33), tratando a respeito do conceito de propriedade dado por Aristóteles:

[...] no entendimento de Aristóteles, a Propriedade reúne as características da Propriedade Privada e da comum, ou seja, o domínio é privado, mas o uso que dela se faz deve dar-se como se fosse comum. Portanto, a Propriedade Privada para Aristóteles tem uma destinação 
comum, devendo adequar-se aos interesses da comunidade, dentre os quais destaca-se a qualidade ambiental da cidade.

Já, para Thomas Hobbes (1979, p. 77), não existe propriedade privada no estado de natureza: "conseqüência da mesma condição é que não há propriedade, nem domínio, nem distinção entre o meu e o teu; só pertence a cada um aquilo que ele é capaz de conseguir, e apenas enquanto for capaz de conservá-lo".

Segundo Thomas Hobbes (1979, p. 151), a propriedade não é um direito natural, mas sim uma concessão do poder soberano, através de leis civis: "portanto, que a introdução da propriedade é um efeito do Estado, que nada pode fazer a não ser por intermédio da pessoa que o representa, ela só pode ser um ato do soberano, e consiste em leis que só podem ser feitas por quem tiver o poder soberano".

De acordo com John Locke (1978), o direito de propriedade é anterior ao surgimento da sociedade civil, sendo assim, é um direito natural; e surge do trabalho empregado sobre a coisa:

Deus ordenava, e as necessidades obrigavam ao trabalho. Pertencia-lhe o que não fosse possível arrebatar-lhe, estivesse onde estivesse. Daí se vê que dominar ou cultivar a terra e ter o domínio estão intimamente conjugados. Um deu direito a outro. Assim, Deus mandando dominar, concedeu autoridade para a apropriação; e a condição da vida humana, que exige trabalho e material com que trabalhar, necessariamente introduziu a propriedade privada.

A propriedade é o direito real em plenitude, aproveitando o seu titular de todos os direitos inerentes, é o que verifica-se nos dispositivos do Código Civil, que garantem ao proprietário a faculdade de usar e gozar de seus bens, e de reaver do poder de quem quer que injustamente os possua.

No Direito romano, o direito de propriedade passa de um direito coletivo para um direito absoluto. Nos primórdios do Direito romano, a relação jurídica, referente à propriedade envolvia, os objetos destinados à sobrevivência, passando a englobar também os bens pessoais possíveis 
de troca, posteriormente, em uma evolução, englobaria os meios de produção e trabalho.

Fernanda de Salles Cavedon (2003, p. 12), através de Levy, questiona este absolutismo do direito de propriedade "A Propriedade no Direito Romano é freqüentemente apontada como direito absoluto, exclusivo e perpétuo, possuindo como elementos o jus utendi, fruendi et abutendi. Levy questiona este posicionamento, ressaltando que os textos romanos não exprimem literalmente estes elementos".

Segundo Fernanda de Sales Cavedon (2003, p. 12), a concepção de propriedade no direito romano não permaneceu estático: "[...] mas se modificou ao acompanhar a evolução política, social e cultural, que refletiu sobre as normas jurídicas dando-lhes um sentido mais social”.

Já, na Idade Média, a propriedade perde seu caráter exclusivo, em decorrência do regime feudal, onde ocorria a delegação do suserano ao vassalo em troca de benefícios financeiros.

O Código Civil Francês, conhecido como Código de Napoleão, já impõe restrições ao direito de propriedade, estabelecendo este código que o exercício deste direito fundamental condiciona-se às limitações regulamentares, tratado em seu artigo $544^{1}$.

O caráter absoluto da propriedade sempre foi amenizado pela sociedade, submetendo-o a regras e limites estabelecidos pelo Estado, visando atender aos interesses públicos.

Portanto, todos estão sujeitos ao poder soberano estatal que, de acordo com os anseios sociais, podem atingir ou limitar o poder absoluto da propriedade, como é o caso da função social, que pode ser considerada como uma afirmação de um princípio basilar do Direito Público, qual seja, a prevalência dos interesses coletivos sobre os interesses individuais. Extrai-se este pensamento, fazendo-se uma leitura do art. $5^{\circ 2} \mathrm{da}$

1 Artigo 544: A propriedade é o direito de fruir e dispor das coisas da maneira mais absoluta, contanto que não se faça dela um uso proibido pelas leis ou pelos regulamentos.7

2 Art. $5^{0}$ : Todos são iguais perante a lei, sem distinção de qualquer natureza, garantindo-se aos brasileiros e aos estrangeiros residentes no País a inviolabilidade do direito à vida, à liberdade, à igualdade, à segurança e à propriedade, nos termos seguintes: XXII - é garantido o direito de 
Constituição da Republica Federativa do Brasil de 1988, onde consta as garantias do cidadão, entre elas a propriedade, condicionado, porém, ao atendimento da função social (BRASIL, 1988).

Portanto, o meio ambiente, por se tratar de um interesse difuso e coletivo deve limitar as faculdades de usar, gozar, fruir e dispor da propriedade pelo particular, faculdades tidas como estáticas da propriedade, que também é composta por um caráter dinâmico, a propriedade dinâmica.

\section{Propriedade dinâmica}

O uso, gozo, disposição e o direito de reaver devem ser vistos como direitos estáticos da propriedade, e são assim concebidos, pois inerentes e intrínsecos ao direito do proprietário, não sofrendo alterações com a evolução e mudanças sociais. Tais direitos são gerados pelo simples fato do particular ter a propriedade de determinado objeto.

A propriedade tem duas facetas sendo elas: estática e dinâmica. A propriedade estática refere-se à propriedade imobiliária, os créditos e relações jurídicas derivadas, regidas pelo Código Civil quase em sua totalidade. Em contrapartida, a propriedade dinâmica está relacionada com as atividades econômicas, industriais e comerciais, que se destinam "a produzir e promover a circulação, a distribuição e consumo de bens" (VAZ, 1993, p. 96).

Segundo Isabel Vaz (1993, p. 159):

retirar o capital, os bens de produção do estado de ócio (aspecto estático), consistem, pois, em utilizá-los para produzirem novas riquezas, gerando empregos e sustento aos cooperados da empresa e à comunidade. É substituir o dever individual, religioso, de dar esmola pelo dever jurídico inspirado no compromisso com a comunidade, de proporcionar-lhe trabalho útil e adequadamente remunerado.

propriedade; XXIII - a propriedade atenderá a sua função social. 
Esta necessidade de retirar o ócio da propriedade, de deixar ela de ser eminentemente estática para tornar-se dinâmica, utilizando-a para a geração de riquezas sociais, é dever do proprietário.

Para Rogério Gesta Leal (1998, p. 46):

com o modo de produção capitalista, a nova forma de Propriedade que ganha relevo em pouco tempo é a Propriedade industrial, que vem se juntar a Propriedade imobiliária, todos de caráter absolutamente individual e destinadas a atender expectativas particulares e setoriais de uma parcela da sociedade, sendo idealizadoras de que esta Propriedade tenha um fim em si mesma, ou seja, servir de capital para gerir mais capital.

Este caráter dinâmico dá um caráter mais útil e proveitoso à propriedade, de acordo com Carlos Alberto Dabus Maluf (1997, p. 3): “As inúmeras restrições e limitações que se fazem hoje ao seu livre exercício, imprimindo-lhe um caráter, sobretudo dinâmico, socialmente mais útil e proveitoso, não visam senão a este objetivo mesmo[...]”.

A dinâmica da propriedade é gerada da necessidade imposta pela sociedade de obrigar ao particular a dar uma destinação útil a propriedade que detém; esta destinação é a geração de lucro ou de riquezas que advém da necessidade imposta pela ordem econômica vigente.

Segundo Eros Roberto Grau (1983), citado por Vaz (1993, p. 121), a propriedade dinâmica é vista como "função" e "dever", sendo instrumento de uma função "quanto é vista e entendida como atividade". A utilização de "função" por Eros Roberto Grau, pode remeter a uma interpretação que condiciona o aparecimento da dinâmica da propriedade à função social, haja vista ser a função social a responsável por impulsionar o proprietário, obrigando a dar uma destinação econômica/ social à propriedade.

A propriedade, vista sob o prisma econômico, é uma forma de alocamento de recursos, portanto, sua eficiência será medida pela capacidade de criar recursos. Sob esta ótica, temos a dinâmica da propriedade, 
capacidade de geração de riquezas pela propriedade, retirando-a da estática e inserindo-a em uma eficácia otimizadora.

De acordo com Rogério Gesta Leal (1998, p. 46-47):

é de se notar que a tendência de conceber a propriedade como um fim em si mesma, neste período da história, já fora prenunciada por Hobbes e estava totalmente implícita em outros autores do liberalismo clássico, como Bentham. Para este autor, o fim último a que visava os contratos sociais era a maximização da utilidade total dos membros da sociedade. Embora arrolasse vários tipos de prazer, incluindo os não-materiais, ele sustentava que a riqueza era tão essencial para a obtenção de todos os demais prazeres, que podia ser tomada como medida do prazer ou da utilidade. Assim, o autor conclui que todo o indivíduo integrado na nova ordem burguesa buscaria maximizar ilimitadamente sua riqueza. Significa dizer que esta maximização tornou-se indistinguível do fim supremo da acumulação da propriedade material de cada indivíduo. Deste modo, entendemos porque a propriedade, e não a instituição da propriedade, tornou-se um fim em si mesma.

A dinâmica da propriedade, atendida pela geração de riqueza, é extremamente relevante na vida e história humana. Segundo Aristóteles (1988, p. 27), escrevendo sobre a importância da propriedade:

muitas vezes considera-se como riqueza a abundância de metais cunhados, porque tal abundância representa o objeto da ciência da indústria e do pequeno comércio. Por outro lado, vê-se a moeda como uma vã brincadeira sem qualquer fundamento natural, pois que aqueles mesmos que delas fazem uso podem realizar outras convenções, e a moeda deixará de ter valor ou utilidade, e o homem rico em metais cunhados faltarão os gêneros de primeira necessidade. Estranha riqueza aquela que, por maior que seja, não impede que seu possuidor morra de fome - como aquele Midas da fábula, cujo desejo cúpido transformava em ouro as iguarias que the serviam.

A produtividade pode ser considerada a imposição social para a dinâmica da propriedade, haja vista ser ela fator preponderante para a determinação da desapropriação de terras, ditas como improdutivas e que 
não atendem a função social e aos interesses da coletividade; caso o proprietário desse dinâmica a sua propriedade, este quesito produtividade, estaria sendo atingido, pois o interesse social é a produção de algum tipo de riqueza, benéfica à sociedade, pelo particular.

De acordo com Rogério Gesta Leal (1998, p. 51):

se o titular do direito não utiliza as faculdades inerentes ao domínio para extrair do bem os frutos que este tem capacidade de produzir, ficará sujeito às cominações legais, para que a propriedade possa ser recolocada em seu caminho normal. A Função social, aqui, visa justamente a fazer com que ela seja utilizada de maneira a cumprir o fim a que se destina, ao menos dogmaticamente, não gerando contraposição entre os interesses individuais e coletivos.

Ainda, tratando das penalidades, Isabel Vaz (1993, p. 321):

ao impor ao proprietário o dever de utilizar o imóvel de modo adequado ao pleno desenvolvimento das funções sociais da cidade, o legislador dispõe de vários meios para obrigá-lo ao cumprimento da norma: a desapropriação, traduzindo limitação quantitativa negativa, implicando a transferência compulsória do bem a município, mediante prévia justa indenização em dinheiro, tradicionalmente praticada; o parcelamento ou a edificação compulsória (facere); a tributação excessiva e a desapropriação paga através de títulos da dívida pública, resgatáveis em até dez anos.

Segundo Isabel Vaz (1993, p. 322), a propriedade dinâmica pode se apresentar sob três formas de setores geradores da atividade econômica:

o aspecto dinâmico das propriedades, tal como concebemos, repousa, sobretudo, na idéia de ação, de atividade econômica organizada. Esta pode ser exercida diretamente sobre a natureza, como o cultivo da terra, as atividades extrativas ou agropastoris e outras, enquadráveis no chamado setor primário de produção. Num plano intermediário, encontram-se os setores industriais de transformação, ora produtores de 
máquinas e equipamentos, a indústria têxtil e siderúrgica, por exemplo, agrupados sob a denominação genérica de setor secundário. Em uma etapa mais desenvolvida, localizam-se as atividades produtoras de bens mais sofisticados, possibilitadas pelo emprego de tecnologias geradas no país ou importadas, como os serviços de automação, da química fina, aparelhos médicos, computadores, aos quais corresponde a criação, tanto de novos bens de produção, como de outros produtos, serviços e bens de consumo.

A geração de riqueza e, consequentemente, o atendimento da dinâmica da propriedade, fazem a propriedade responder a uma necessidade econômica, segundo Rogério Gesta Leal (1998, p. 50-51):

o indivíduo passa a ser encarado como um meio para cumprir uma função, enquanto a propriedade é formada para responder a uma necessidade econômica. Conforme essa concepção, ela é uma situação jurídica puramente objetiva; o ordenamento não protege o direito subjetivo de usar a coisa segundo a vontade, mas garante, tão-somente, a liberdade do possuidor da mesma de satisfazer a função social que lhe compete pelo fato de ser o detentor da riqueza.

A geração de riqueza, atendendo a função social já é tratada por Duguit, de acordo com Rogério Gesta Leal (1998). Para Duguit, o direito positivo não protege nem deve proteger o direito subjetivo absoluto do proprietário, mas simplesmente garante a liberdade ao possuidor de constituir riqueza com a finalidade de cumprir com a função social.

Esta questão da função da propriedade é também tratada por Isabel Vaz (1993, p. 318):

o aperfeiçoamento do conceito de função social se revela quando o legislador impõe, não apenas uma "limitação dimensional" à propriedade, cujo titular "sofre" as conseqüências da redução quantitativa de seu patrimônio, mas quando passa a exigir do proprietário uma utilização do imóvel conforme aos princípio da função social. De sujeito 
"passivo" da intervenção do estado, o proprietário passa a ser "co-partícipe" da ação estatal na realização dos fins da ordem econômica e financeira.

A função social fomenta o aparecimento da propriedade dinâmica, pois pressiona o proprietário a dar uma destinação à propriedade, por ser compelido pela função social.

\section{Função social}

A sociedade e as relações humanas estão em constante modificação, os dispositivos legais devem renovar-se para serem coerentes às aspirações e anseios sociais. Isso ocorreu com o direito de propriedade, que teve uma releitura através da função social.

Esta evolução histórica é tratada por Luiz Edson Fachin (1988, p. 16):

a propriedade, para a Declaração dos Direitos do Homem e do Cidadão, constitui um direito inviolável e sagrado. Tanto o Código francês quanto o Código italiano de 1865, estatuíam que a propriedade é o direito de gozar e dispor do bem de modo absoluto. A partir da constituição Weimar, há progressivo reconhecimento de uma ordem econômica e social com implicações para a questão da propriedade, de forma a construir uma nova etapa frente ao já superado laisser faire, laisser passer. A Revolução Francesa procurou dar um caráter democrático a propriedade, abolindo privilégios, cancelando direitos perpétuos, porém, este fito da burguesia ficou diretamente condicionado aos seus interesses econômicos e políticos, de forma que a propriedade alterava as suas concepções tradicionais para servir a uma nova classe social em busca de poder: a burguesia. A nova fórmula de dominação econômica e política do feudalismo, que sucedeu ao Estado universal dos romanos, foi substituída pela Revolução Francesa com o império dos princípios da igualdade, soberania e justiça. 
Uma releitura é feita por Álvaro Borges de Oliveira (2010) sobre a desnecessidade de exercer a função social, uma vez que o particular não tem o dever de dar finalidade social a sua propriedade, contudo, a propriedade privada, deve estar inserida socialmente, estar em consonância com a sociedade.

A função social da propriedade pode ser entendida como um conjunto de normas da Constituição que visa, por vezes, até com medidas de grande gravidade jurídica, recolocar a propriedade na sua trilha normal, e em consonância com os anseios sociais.

Propriedade e função social são princípios co-existentes e inseparáveis, sendo a função social intrínseca à propriedade. Possuem, ambas, em nosso ordenamento jurídico, "status" de princípios constitucionais.

De acordo com Pinto Ferreira (1989, p. 245):

não se deve abolir a propriedade privada, porém, emprestar-lhe uma função social. O conceito de propriedade provém do direito romano, que a definiu como o jus utendi, fruendi et abutendi re sua, quatenus ratio jus patitur, isto é, o direito de usar, fruir e dispor da própria coisa, até onde permitia o direito. Este permissivo do direito deve ser ajustado à vida social contemporânea, no sentido de atribuir à propriedade uma função social, como a garantia da dignidade da pessoa a ser generalizada para todos.

A função social tem como objetivo contemplar os interesses coletivos e garantir a promoção do bem comum. A função social determina que o proprietário, além de um poder sobre a propriedade, tenha o dever com a sociedade. Este dever é de usar a propriedade dando a ela a melhor destinação sob a ótica dos interesses sociais.

De acordo com Fernanda de Salles Cavedon (2003, p. 83) “[...] integram a Função Social da Propriedade os interesses de terceiros, representados pelo interesse da Sociedade, além do interesse do proprietário, bem como o prudente arbítrio no sopesamento e conciliação de tais interesses." 
Esta função social não integraria a essência da propriedade, mas sim a sua utilização, de acordo com Luiz Edson Fachin (1988, p. 16): "A doutrina da função social da propriedade corresponde a uma alteração conceitual do regime tradicional; não é, todavia, questão de essência, mas sim pertinente a uma parcela da propriedade que é a sua utilização".

A propriedade tem uma função social de modo a impor ao proprietário a exploração do bem, mantendo a sua utilidade, concorrendo para o bem comum, caso não ocorra, esta utilidade coletiva na exploração, a propriedade não se justifica.

O artigo $186^{3}$ da Constituição da República Federativa do Brasil (BRASIL, 1988) torna a propriedade privada não mais absoluta, seu uso, gozo, fruição e disposição não podem opor-se aos interesses gerais e coletivos.

Pode-se entender o princípio da propriedade e a função social como um poder/dever, sendo o poder da sociedade de obrigar o proprietário a pensar nos interesses sociais, quando der a destinação que lhe interessar, e um dever do proprietário de acatar, cumprir as determinações e anseios sociais e cumprir a função social da propriedade. Exemplo disso são as áreas de preservação permanente e as reservas legais, onde a coletividade verificou a importância de sua preservação e manutenção e impuseram aos proprietários o dever de cumprir esta determinação, regulando a utilização destas porções de terras nas propriedades privadas.

Além da função econômica, a propriedade deve obedecer aos anseios ambientais coletivos, devendo atender, também, a função social ambiental, portanto, a função social da propriedade engloba a função ambiental, ganhando os contornos do Direito Ambiental.

3 Art. 186: A função social é cumprida quando a propriedade rural atende, simultaneamente, Segundo critérios e graus de exigência estabelecidos em lei, aos seguintes requisitos: I - aproveitamento racional e adequado; II - utilização adequada dos recursos naturais disponíveis e preservação do meio ambiente; III - observância das disposições que regulam as relações de trabalho; IV exploração que favoreça o bem estar dos proprietários e dos trabalhadores. 


\section{Função social ambiental da propriedade}

O artigo 225 da Constituição da República Federativa do Brasil de 1988 (BRASIL, 1988) consagra, constitucionalmente, o direito ao meio ambiente, ecologicamente equilibrado, é, portanto, consagrador da função ambiental da propriedade.

A função ambiental da propriedade é um direito de terceira geração, segundo Norberto Bobbio (1997), desta mesma maneira, de modo subjetivo e indeterminado, a todo gênero humano, incumbindo ao Estado e à coletividade à proteção em benefício das presentes e futuras gerações.

A preocupação, com a preservação do meio ambiente, transcende o plano das presentes gerações, atuando em favor das gerações futuras, sendo objeto de regulação normativa que ultrapassa o direito nacional de cada estado soberano, projetando-se no plano das declarações internacionais, como o Tratado de Kyoto, fomentador dos créditos de carbono, mecanismo que pode atender aos princípios tidos como inconciliáveis como os da preservação ambiental e do desenvolvimento econômico.

Segundo Clarissa Ferreira Macedo D`Isep (2009, p. 157) “é com base na função ambiental que podemos cobrar a utilização social dos bens ambientais, isto é, o uso, gozo e fruição de tais bens - que são de uso comum do povo - devem ocorrer com vista ao bem-estar de todos".

Os normativos jurídicos tratam do meio ambiente como patrimônio público, coletivo, necessariamente assegurado e protegido pelos organismos sociais e pelas instituições estatais, sendo de titularidade coletiva.

Dentro desse contexto, a proteção da flora e da fauna, e o dever de sua observância pelo proprietário particular, sendo vedado a ele práticas que coloquem em risco o meio ambiente e, portanto, a coletividade, pode ser alvo de descumprimento da função social da propriedade.

Segundo Roxana Cardoso Brasileiro Borges (1999, p. 109), a função social ambiental da propriedade: "consiste, em sentido amplo, nos deveres atribuídos ao proprietário de utilização adequada dos recursos naturais disponíveis e preservação do meio ambiente". 
O descumprimento da função social ambiental da propriedade advém do dispositivo legal supra citado, bem como o artigo 186, II, da Constituição Federal de 1988, que determina que a função social é cumprida pela propriedade rural se esta utilizar adequadamente os recursos naturais e cumprir a preservação do meio ambiente.

Segundo Roxana Cardoso Brasileiro Borges (1999, p. 109):

a função ambiental da propriedade, na análise que se realiza, tendo em vista precipuamente a proteção dos recursos naturais, é um dos quatro elementos que compõe o conteúdo constitucional de função social da propriedade, que é compreendido pelo art. 186 da Constituição Federal de 1988.

A defesa da integridade do meio ambiente, quando esta sofrer atividade predatória, que coloque em risco a sua existência pode justificar ao Estado a reação e imposição de sanções, que possam atingir ao direito do proprietário; pois o imóvel rural que não se ajusta, quando do processo de exploração econômica, aos fins determinados no art. 185 da Constituição da República Federativa do Brasil de 1988, claramente descumpre o princípio da função social.

Sendo assim, o descumprimento da função social ambiental da propriedade pode gerar ao proprietário obrigações e sanções impostas pelo Estado, visando garantir o direito coletivo de todos terem um meio ambiente saudável e equilibrado.

\section{Função social ambiental da propriedade como limitadores do direito de propriedade}

Com a criação de uma legislação protetora do meio ambiente, alguns direitos individuais foram moldados com o objetivo de adequarem-se à proteção ambiental regulamentada, dentre eles a propriedade.

Segundo Roxana Cardoso Brasileiro Borges (1999, p. 44): 
diante da preocupação em se garantir a proteção do meio ambiente, a propriedade é um dos institutos jurídicos afetados pela legislação ambiental, estando seu conceito clássico em condição de sofrer alterações para que o exercício desse direito seja compatível com a proteção ambiental.

Roxana Cardoso Brasileiro Borges (1999, p. 45) ainda escreve sobre os interesses confrontantes dos proprietários e da sociedade em geral: "por ser a proteção do meio ambiente um interesse difuso, a propriedade passa a estar vinculada a interesses outros que podem não corresponder exatamente aos interesses imediatos do proprietário."

Portanto, o Direito Ambiental impõe restrições e limitações ao Direito da propriedade, determinando aos proprietários condutas que devam ser respeitadas e obedecidas sob pena de estarem, desrespeitando os princípios deste ramo do Direito.

Estas limitações e restrições advém do direito fundamental de todos os cidadãos terem o direito ao meio ambiente preservado, consubstanciado na Constituição da República Federativa do Brasil de 1988.

Segundo Fernanda de Salles Cavedon (2003, p. 88): “[...] a proteção legal do Meio Ambiente passa a incidir sobre direitos e condutas privadas, muitas vezes acarretando a sua limitação, direcionando-as no sentido de se adequarem aos preceitos de ordem ambiental."

Continua Fernanda de Salles Cavedon (2003, p. 88):

[...] visto que a proteção do Meio Ambiente caracteriza-se como um Interesse Público que, invariavelmente, deverá interferir nas atividades e Interesses Privados no sentido de adequá-las aos preceitos ambientais. É um ramo intermediário, que trabalha com variáveis públicas e privadas, na busca de um meio-termo. Portanto, o Direito Ambiental atua sobre um Conflito de interesses (público $\mathrm{X}$ privado), visando sua harmonização [...].

Portanto, a regulação proposta pelo Direito Ambiental tem influência direta sobre a propriedade privada e os direitos individuais 
decorrentes desta relação entre propriedade e particular. Sobre a limitação do direito de propriedade, escreve Roxana Cardoso Brasileiro Borges (1999, p. 113):

[...] a proteção ambiental deve ser vista não apenas como uma limitação do direito de propriedade, mas também como uma proteção à própria propriedade rural, para que a utilidade desta não seja ameaçada por lesões ambientais que possam advir de seu uso inadequado, em desacordo com as regras de manutenção do equilíbrio ecológico. Esta visão de dupla função protetora é facilmente obtida a partir da leitura dos $\S \S 2^{\circ}$ e $3^{\circ}$ do art. $9^{\circ}$ da Lei n. 8.629/93: ao mesmo tempo em que protege o meio ambiente, protege-se também a propriedade.

Por força de dispositivos constitucionais como o artigo 225 e o artigo $5^{\circ}$ da Constituição da República Federativa do Brasil de 1988, o meio ambiente equilibrado tem reconhecimento de direito fundamental de todos os cidadãos.

Estas limitações, instituídas pelo Direito Ambiental ao Direito de Propriedade, podem ser as áreas de preservação permanente e as reservas legais, haja vista a norma ambiental de preservação e manutenção de determinadas áreas de vegetação e floresta incidir no direito de propriedade do particular.

\section{Reserva legal}

As florestas de domínio privado não podem ser livres e irrestritamente exploradas. As que não são de preservação permanente e não estão sujeitas a limitações podem ser exploradas, sendo obrigatório o atendimento a algumas condições impostas pelo Código Florestal.

De acordo com Roxana Cardoso Brasileiro Borges (1999, p. 128): "Sua regulamentação é feita pelos arts. 16 e 44 do Código Florestal (Lei n. 4.771/65). O objetivo das reservas legais é a preservação da diversidade biológica de espécimes da fauna e, principalmente, da flora." 
Nas regiões Leste Meridional, Sul e Centro-Oeste, está na parte Sul. As derrubadas de florestas nativas, primitivas ou regeneradas, só serão permitidas se conservada área de, no mínimo, 20\% do imóvel, é o que prevê o art. 16, "a” do Código Florestal.

Esta área é diferente, na Região Norte e na parte norte da região Centro-Oeste, que compreende os Estados do Acre, Pará, Amazonas, Roraima, Rondônia, Amapá e Mato Grosso, mais as regiões situadas nos Estados de Tocantins e Goiás, e ainda o Estado do Maranhão. De acordo com o art. 44 do Código Florestal, a cobertura florestal exigida é de no mínimo $50 \%$, podendo chegar a $80 \%$, se a cobertura for constituída de fitofisionomias florestais.

O $\S 2^{\circ}$ do art. 16 e o $\S 1^{\circ}$ do art. 44 do Código Florestal, chama de reserva legal essa área mínima de conservação obrigatória, onde não é permitido o corte raso da vegetação, tornando-se uma restrição administrativa imposta a quase todos os imóveis rurais.

O caput do art. 16 do Código Florestal diz apenas que as florestas de domínio privado podem ser exploradas, porém com restrições, estando excluídas as áreas sujeitas do regime de utilização limitada e as de preservação permanente, conforme arts. $2^{\circ}$ e $3^{\circ}$ do Código. Esta restrição é dirigida aos imóveis que tenham floresta nativa, primitiva ou regenerada.

A Lei n. 7.803 de 1989 (BRASIL, 1989) acrescentou o $§ 2^{\circ}$ ao art. 16, dispondo:

a reserva legal, assim entendida a área de, no mínimo 20\% (vinte por cento) de cada propriedade, onde não é permitido o corte raso, deverá ser averbada à margem da inscrição da matrícula do imóvel, no Registro de Imóveis competente, sendo vedada a alteração de sua destinação, no caso de transmissão, a qualquer título, ou de desmembramento de área.

O mesmo dispositivo legal acrescentou a reserva legal de $50 \%$ na região Norte e na parte norte da região Centro-Oeste. Não são todos os imóveis particulares do território que devem respeitar a área de reserva legal de $20 \%$, só sendo obrigatória nas propriedades das regiões Leste 
Meridional, Sul, parte sul da região Centro-Oeste, e por força do $\S 3^{\circ}$ nas áreas de cerrado.

A Reserva Legal, de acordo com a redação dada pela Medida Provisória n. 1.956-50/00, manteve, basicamente, os índices de manutenção das florestas e vegetações, sendo de no mínimo $20 \%$ da propriedade rural, com exceção de propriedades situadas na área de floresta localizada na Amazônia Legal ${ }^{4}$, onde os índices podem chegar a $80 \%$.

Caso a propriedade esteja situada em área recoberta por vegetação de cerrado, localizada na Amazônia Legal, a Reserva Legal será de, no mínimo, $20 \%$, e $15 \%$ a ser compensada em outra área localizada na mesma microbacia.

A Medida Provisória prevê, ainda, a possibilidade de redução e ampliação da Reserva Legal, na área da Amazônia Legal, em índices de redução/ampliação de até $50 \%$.

Sendo assim, através destes dispositivos legais, o proprietário particular é obrigado a manter e preservar determinadas áreas, sendo nominadas como reservas legais, sua porcentagem de área preservada varia de acordo com a localização da propriedade privada. Além da reserva legal, outra limitação administrativa ao direito de propriedade são as áreas de preservação permanente, determinadas no Código Florestal.

\section{Áreas de preservação permanente}

O Código Florestal (Lei n. 4.771, de 15 de setembro de 1965), no art. $2^{\circ}$, considera de preservação permanente as florestas e demais formas de vegetação, situadas em locais essenciais à manutenção de um meio ambiente hígido.

4 A chamada Amazônia Legal brasileira abrange os Estados do Amazonas, Amapá, Acre, Mato Grosso, oeste do Maranhão, Pará, Rondônia, Roraima e Tocantins, com uma superfície de aproximadamente 5 milhões de $\mathrm{Km} 2$, ou seja, $60 \%$ do território nacional. Ela abriga metade das espécies conhecidas de plantas tropicais, uma variedade de peixes maior que a do Oceano Atlântico e a maior bacia hidrográfica do mundo, com aproximadamente 80 mil quilômetros de rios navegáveis. 
De acordo com Paulo Affonso Leme Machado (2004, p. 554):

o espírito do Código Florestal, a sua interpretação teleológica nos leva a afirmar que as florestas de preservação permanentes não são suscetíveis a exploração. Alias essa a correta interpretação do art. 16 do Estatuto Florestal, quando prevê como ressalva para a exploração da floresta de domínio privado, o fato da mesma ser de preservação permanente.

A proteção de certas áreas já era previsto na legislação de 1934. A respeito disso discorre Osny Duarte Pereira (1950, p. 210):

sua conservação não é apenas por interesse público, mas por interesse direito e imediato do próprio dono. Assim como ninguém escava o terreno dos alicerces de sua casa, porque poderá comprometer a segurança da mesma, do mesmo modo ninguém arranca as árvores das nascentes das margens dos rios, nas encostas das montanhas, ao longo das estradas, porque poderá vir a ficar sem água, sujeito a inundações, sem vias de comunicação, pelas barreiras e outros males conhecidos resultantes de sua insensatez.

Esta visão corresponde com a data da publicação da obra. Com o passar do tempo, a sociedade deixou de preocupar-se com a proteção do meio ambiente sob o pretexto do desenvolvimento e a necessidade de terras cultiváveis, isso levou a uma degradação desmedida do meio ambiente.

A Lei da Política Nacional do Meio Ambiente, n. 6.938 de 1981, no art. 18, transformou as florestas e demais formas de vegetação permanente em reservas ou estações ecológicas, fazendo expressa referência ao art. $2^{\circ}$ do Código Florestal. O intuito foi de assegurar a tais áreas maior proteção, evitando a sua exploração e consequente degradação. A regulamentação de tais áreas foi a resposta do Direito Ambiental à degradação, causada sob a motivação do desenvolvimento econômico. 
De acordo com Roxana Cardoso Brasileiro Borges (1999, p. 122) “as áreas de preservação permanente são espaços territoriais especialmente protegidos, de proteção integral".

O Código Florestal Brasileiro passou por profundas transformações a partir do ano de 2000, de acordo com Fernanda de Salles Cavedon (2003, p. 103):

[...] as Áreas de Preservação Permanente instituídas pelo Código Florestas Brasileiro, que passou por profundas transformações a partir do ano de 2000, especialmente pela Medida Provisória n ${ }^{\circ} 1.956$, de 26 de maio de 2000, mas também pela Lei 9.985 de 2000 que, ao instituir o Sistema Nacional de Unidades de Conservação da Natureza revogou o art. 18 da Lei da Política Nacional do Meio Ambiente, que transformava as Áreas de Preservação Permanente em reservas ou estações ecológicas e, no ano de 2002, pela Resolução do CONAMA n³03, que redefiniu os parâmetros, definições e limites das APPs.

Para promover a preservação das florestas e vegetações existentes, foram instituídas pelo Código Florestal as Áreas de Preservação Permanente, determinando que a vegetação que cobre determinadas áreas, quer seja por sua função protetora, quer seja por sua relevância ecológica, devem ser mantidas incólumes, sendo vedada, qualquer forma de exploração econômica.

A Lei n. 4.771, de 15 de setembro de 1965, traz a definição para área de preservação permanente, em seu art. $1^{\circ}, \S 2^{\circ}$, II, que as define como:

área de preservação permanente: área protegida nos termos dos arts. $2^{\circ}$ e $3^{\circ}$ desta Lei, coberta ou não por vegetação nativa, com a função ambiental de preservar os recursos hídricos, a paisagem, a estabilidade geológica, a biodiversidade, o fluxo gênico de fauna e flora, proteger o solo e assegurar o bem-estar das populações humanas. 
Segundo Paulo Affonso Leme Machado (2004, p. 554), mesmo não sendo permitido o corte raso nessas áreas, elas não perderiam sua utilidade econômica, de acordo com o autor:

não diria que estas florestas deixam de ter finalidade econômica, pois que melhor investimento do que através dessas florestas assegurar-se o bem-estar psíquico, moral, espiritual e físico das populações? Além disso, conservando-se as espécimes da fauna em seu habitat, pode-se mensurar e quantificar economicamente a existência das florestas de preservação permanente.

Sendo assim, as áreas de preservação permanente não tirariam a função econômica da propriedade, contribuindo para a manutenção da integridade ambiental, beneficiando diretamente a coletividade e o proprietário.

As áreas de preservação permanente, segundo Antônio Herman V. Benjamin (1997), podem ser diferenciadas em duas categorias, as legais e as administrativas. Segundo o autor "As áreas de preservação permanentes legais são chamadas como tais porque sua delimitação ocorre no próprio Código Florestal; e as segunda são assim denominadas porque sua concreção final depende da expedição de ato administrativo da autoridade ambiental competente" (BENJAMIN, 1997, p. 26).

As áreas de preservação permanente ditas como legais, são aquelas citadas pelo Código Florestal em seu art. $2^{\circ}$. Segundo Roxana Cardoso Brasileiro Borges (1999, p. 123), discorrendo sobre o art. $2^{\circ}$ do Código Florestal:

a alínea $a$ desse artigo, considera de preservação permanente a vegetação natural localizada ao longo dos rios ou de qualquer outro curso d'água desde o seu nível mais alto em faixa marginal. As alíneas $b$ e $c$ referem-se a vegetação ao redor das lagoas, lagos ou reservatórios d'água naturais ou artificiais e nas nascentes, ainda que intermitentes e nos chamados olhos d'água, qualquer que seja a sua situação topográfica. 
A resolução do CONAMA n. 303/02 estabeleceu parâmetros e limites às áreas de preservação permanente, bem como expandiu, ainda mais, o rol enunciado no art. $2^{\circ}$ do Código Florestal.

Destaca-se que a Resolução do CONAMA trata de Áreas de Preservação Permanente, enquanto o Código Florestal refere-se à preservação permanente de florestas e demais formas de vegetação. Isso ocorre porque a Resolução incluiu áreas sem vegetação ou florestas, como por exemplo, as dunas, caracterizando-as como espaços e ambientes com função ambiental específica.

Ainda, o Código Florestal previu, em seu art. $2^{\circ}$, as áreas urbanas, que deverão observar os dispostos do Plano Diretor e leis de uso do solo.

A autora Fernanda de Salles Cavedon (2003, p. 107), fazendo referencia à competência municipal de legislar sobre as áreas de preservação permanente, pontua:

é preciso esclarecer que, com esse artigo, não se quer dizer que a administração pública municipal possa deliberar sobre as Áreas de Preservação Permanente, dando-lhes destinação diferente daquela fixada pelo Código Florestal, pois deixa claro a condição indispensável de respeito aos limites do art. $2^{\circ}$. Portanto, deverão os Planos Diretores municipais adotarem as restrições e limites impostos pelo Código Florestal.

Já o segundo tipo de Áreas de Preservação Permanente, as ditas administrativas, instituídas pelo Poder Público através de ato discricionário, são aquelas fixadas pelo art. $3^{\circ}$ do Código Florestal. Com a edição da Medida Provisória n. 956-50/00, alterou-se o entender sobre a supressão das florestas e demais vegetações, consideradas de preservação permanente; antes só poderiam ser suprimidas as descritas no art. $3^{\circ}$ do Código Florestal, com a nova redação dada pela medida Provisória, passou, a doutrina, a entender possível a supressão também das áreas de preservação permanente elencadas no art. $2^{\circ}$ do Código Florestal. 
De acordo com Paulo Affonso Leme Machado (2004, p. 553): "Os novos caminhos legislativos da política florestal hão de levar a adoção da obrigatoriedade do estudo de impacto ecológico antes do início da supressão parcial ou total da floresta de preservação permanente".

Fernanda de Salles Cavedon (2003, p. 110) explica o artigo $4^{\circ}$ do Código Florestal da seguinte maneira:

o artigo possui sete parágrafos, dos quais cinco fixam critérios a serem atendidos para a autorização da supressão. A supressão de vegetação em área de preservação permanente somente poderá ser realizada mediante autorização do órgão ambiental estadual, com anuência prévia, quando couber, do órgão ambiental federal ou municipal $\left(\$ 1^{\circ}\right)$. No caso de Áreas de Preservação Permanente situadas na área urbana, foram fixados requisitos adicionais. Para a supressão, necessário se faz a autorização do órgão ambiental competente, devendo contar o município com conselho de Meio Ambiente com caráter deliberativo, e Plano Diretor, além da anuência prévia do órgão ambiental estadual competente fundamentada em parecer técnico $\left(\$ 2^{\circ}\right)$. Poderá ser autorizada, ainda, pelo órgão ambiental competente, a supressão de vegetação em Área de Preservação Permanente, desde que a supressão seja eventual e de baixo impacto, o que deve ser definido em regulamento $\left(\S 3^{\circ}\right)$.

Continua Fernanda de Salles Cavedon (2003, p. 110), ao explicitar a redação do art. $4^{\circ}$ do Código Florestal:

o $\S 4^{\circ}$, fixa a necessidade de medidas mitigadoras e compensatórias a serem adotadas pelo proprietário no caso de supressão de vegetação em Área de Preservação Permanente. No que se refere às vegetações nativas protetoras de nascentes, de dunas e mangues, somente se autorizará sua supressão para fins de utilidade pública $\left(\S 5^{\circ}\right)$. O $\S 6^{\circ}$ determina que, nos casos de implantação de reservatório artificial, o empreendedor deverá adquirir ou desapropriar as Áreas de Preservação Permanente que serão criadas no entorno cabendo ao CONAMA fixar os parâmetros e regime de uso, o que foi estabelecido pela Resolução CONAMA n. 302/02. Por fim, $\S 7^{\circ}$ permite o acesso de pessoas e animais às Áreas de Preservação Permanente para a obtenção de água, 
com a condição de que este acesso não exija a supressão de vegetação e nem comprometa a regeneração e manutenção a longo prazo da vegetação.

A própria Medida Provisória n. 1.956-50, de 26 de maio de 2000, no $\S 2^{\circ}$ do art. $1^{\circ}$, incisos IV e V, traz conceitos operacionais ${ }^{5}$, ditos legais, ao definir o que é utilidade pública e interesse socioeconômico.

\section{Importância das reservas legais e das áreas de preservação permanente}

A Reserva Legal e as Áreas de Preservação Permanente são uma forma de proteção das florestas e formas de vegetação nacionais. As Áreas de Preservação Permanente protegem ambientes específicos, desempenhando, estas florestas e vegetação, a função de proteger as terras que revestem; já, a Reserva Legal visa garantir uma reserva de florestas que garantam a integridade do Meio Ambiente, a biodiversidade, a manutenção da flora e da fauna nacionais, e a disponibilidade de recursos naturais às gerações futuras.

Segundo Paulo Afonso Leme Machado (2004, p. 638), existe outra diferença entre as Reservas Legais e as Áreas de Preservação Permanente: "diferenciam-se no que concerne à dominialidade, pois a Reserva Florestal Legal do art. 16 e do art. 44 do Código Florestal somente incide sobre o domínio privado, sendo que as Áreas de Preservação Permanente incidem sobre o domínio privado e público".

Segundo a autora Fernanda de Salles Cavedon (2003, p. 115), fazendo referência às limitações a propriedade, causados pelas Reservas Legais e pelas Áreas de Preservação Permanente: “ambas as formas de

5 Segundo Pasold (2007, p. 42), “o cop legal, por sua vez, como a sua própria denominação esta a indicar é aquele estabelecido em comando jurídico normativo e, portanto, de adoção obrigatória pelos destinatários da norma e neste sentido pode-se afirmar que trata-se de cop impositivo". 
proteção da cobertura vegetal instituídas pelo Código Florestal acarretam limitações ao Direito de Propriedade embasadas no Princípio da Função Social e Ambiental da Propriedade, trazendo benefícios de caráter individual e social".

Estas limitações, impostas pelo Código Florestal, em atendimento aos princípios do Direito Ambiental, tem cada vez mais, permeado as relações individuais de propriedade, pois sua importância envolve o coletivo social, preocupado com a preservação do meio ambiente.

A preocupação ambiental fez o legislador criar leis e normas para preservar e manter o meio ambiente. Antes esparsas no ordenamento jurídico, os mandamentos ambientais ganharam força, culminando na criação do Direito Ambiental como ramo autônomo do Direito.

\section{Considerações finais}

A propriedade é tratada apontando suas relações com as criações do Direito Ambiental, ou seja, a reserva legal e as áreas de preservação permanente. Novamente apresentou-se um conflito entre o Direito Econômico, decorrente da limitação econômica sofrida pela propriedade privada, vista como direito individual e absoluto, que sofre inúmeras restrições, com proeminência a função social, com caráter ambiental, pois o particular é obrigado a preservação e manutenção do meio ambiente para atingir a função social da propriedade, de acordo com corolários constitucionais.

As reservas legais e as áreas de preservação permanente também são limitativas ao direito de propriedade, porém, no presente trabalho, apresentou-se uma visão através de um viés mais econômico, demonstrou-se distinções e o aproveitamento dessas áreas para a geração de riquezas e, consequentemente, lucro ao proprietário, conforme a sua destinação, aproximando, assim, Direito Ambiental e Direito Econômico. Sendo assim, os mecanismos do direito ambiental, qual seja, as reservas legais e as áreas de preservação permanente, aparentemente limitadoras 
do direito de propriedade, bem como, contrárias ao direito econômico, em razão da limitação na geração de riquezas e lucros, através da destinação e utilização proibida nestas áreas, podem ter uma destinação econômica através dos créditos de carbono florestais.

\section{Referências}

ARISTÓTELES. A política. 15. ed. Rio de Janeiro: Ediouro, 1988.

BENJAMIN, A. H. V. Reflexões sobre a hipertrofia do direito de propriedade na tutela da reserva legal e das áreas de preservação permanente. Revista de Direito Ambiental, São Paulo, v. 1, n. 4, p. 41-60, out./dez. 1997.

BOBBIO, N. Direito e estado no pensamento de Emanuel Kant. Tradução de Alfredo Fait. 4. ed. Brasília: Ed. UnB, 1997.

BORGES, R. C. B. Função ambiental da propriedade rural. São Paulo: LTR, 1999.

BRASIL. Institui o novo Código Florestal. Disponível em: <http://www.planalto.gov.br/ccivil_03/leis/L7803.htm〉. Acesso em: 26 out. 2010.

BRASIL. Constituição (1988). Constituição: República Federativa do Brasil. Brasília, DF: Senado Federal, 1988.

CAVEDON, F. S. Função social e ambiental da propriedade. Florianópolis: Visual Books, 2003.

D'ISEP, C. F. M. Direito ambiental econômico e a ISO 14000. São Paulo: Revista dos Tribunais, 2009.

FACHIN, L. E. A função social da posse e a propriedade contemporânea. Porto Alegre: Sergio Antonio Fabris, 1988.

FERREIRA, L. P. Comentários à constituição brasileira. São Paulo: Saraiva, 1989. 
GRAU, E. R. Direito urbano. São Paulo: Revista dos Tribunais, 1983.

HOBBES, T. Leviatã ou matéria, forma e poder de um estado eclesiástico e civil. 2. ed. São Paulo: Nova Cultural, 1979.

LEAL, R. G. A função social da propriedade e da cidade no Brasil. Porto Alegre: Livraria do Advogado, 1998.

LOCKE, J. Carta acerca da tolerância; segundo tratado sobre o governo; ensaio acerca do entendimento humano. 2. ed. São Paulo: Abril Cultural, 1978.

MACHADO, P. A. L. Direito ambiental brasileiro. 12. ed. São Paulo: Malheiros, 2004.

MALUF, C. A. D. Limitações ao direito de propriedade. São Paulo: Saraiva, 1997.

OliveirA, Á. B. de. A função (f(x)) do direito das coisas. Disponível em: <http://www6.univali.br/seer/index.php/nej/article/view/425/367〉. Acesso em: 26 out. 2010.

PASOLD, C. L. Prática da pesquisa jurídica: idéias e ferramentas úteis para o pesquisador do direito. 8. ed. Florianópolis: OAB/SC, 2007.

PEREIRA, O. D. Direito florestal brasileiro. Rio de Janeiro: Borsoi, 1950.

VAZ, I. Direito econômico da propriedade. Rio de Janeiro: Forense, 1993.

Recebido: 11/05/2011

Received: 05/11/2011

Aprovado: 20/08/2011

Approved: 08/20/2011 